U.K. Atomic Energy Authority, Metallurgy Division : Mr. L. Grainger

Mr. L. Grainger has been appointed head of the Metallurgy Division of the United Kingdom Atomic Energy Authority's Research Group at Harwell. He is to succeed Dr. H. M. Finniston, who is being released by agreement to take up appointment with the Nuclear Power Plant Co. Mr. Grainger was born in Sheffield, in 1917, and was educated in Detroit but returned to England in 1933. He was in steel works until the War. He then joined the Admiralty and served with the Royal Air Force as fighter controller during 1943-47, afterwards returning to the Royal Naval Seientific Service to work on co-ordination of metallurgical research, particularly brittle fractures, creep testing, and development of now structural materials. He joined the U.K. Atomic Energy Authority in 1951, and later became head of Laboratories, Research and Development, Springfields. In 1955, he moved to Risley as ehief metallurgist in the Research and Development Branch, becoming deputy director of research and development in 1958. He is the author of "Uranium and Thorium" (Newnes, 1958).

\section{British Cast Iron Research Association:}

Dr. J. G. Pearce, who has been director of the British Cast Iron Research Association since 1924, is to retire. During his tenure of the office he has seen the Association grow steadily both in size and importance. A graduate of the University of Birmingham, he has built up an international reputation and among other distinctions he has received the honorary doctorate of engineering of the University of Aachen. In 1957 he was made C.B.E. A member of the Worshipful Company of Founders, the Livery recently conferred on him its Founders' Medal for his services to the "art and mystery" of iron-founding. Before going to the British Cast Iron Research Association, Dr. Pearce was associated with Sir Arthur Fleming in the planning and organization of the Research and Education Department of the Metropolitan-Vickers Electrical Co., Ltd., and was co-author with Sir Arthur of two text-books on apprentice training and industrial research. He has served on many national and international eommittees and, since 1935, has, among other responsibilities, been chairman of the main committes on cast iron of the British Standards Institution.

Mr. H. Morrogh

Mr. H. Monnogh, at present deputy-director of the British Cast Iron Research Association, has been appointed to succeed Dr. J. G. Pearce as director. Educated at the George Dixon Grammar School, Birmingham, he joined the Association's staff in 1933 and became research manager in 1945. His main work, for which he has received international recognition, has been in connexion with the microstructure of cast irons, and in particular the identification of inclusions and the formation of graphite. It was from the latter work that the discovery of nodular graphite iron, perhaps the most important discovery ever made so far as this material is concerned, was announced in 1948. These contributions have been recognized by the award of gold medals by the Iron and Steel Institute, the Institute of British Foundrymen and the American Foundrymen's Society. He speaks with absolute authority in his own field, and although he himself received no university training, Mr. Morrogh has persistently encouraged higher metallurgical education, not only in the universities but also in the colleges of technology.

\section{Vincenzo Lunardi (1759-1806)}

VINCENZO LUNARDI, who was born two hundred years ago on January 11, 1759, at Lucca in Tuscany, is remembered for having introduced aerostation into Britain. Joseph and Jacques Montgolfier constructed the first fire balloon, in which a sheep, a cock and a duck ascended on September 19, 1783. The first aeronaut in France was Pilâtre de Rozier later that year, and the first in Scotland was James Tytler on August 27, 1784. On September 15, 1784, on the Artillery Ground at Moorfields, the physicianchemist, George Fordyce, inflated a balloon, $33 \mathrm{ft}$. in circumference, with hydrogen before some 200,000 impatient spectators. Its passengers were a pigeon, a dog, a cat and Lunardi, who was secretary to Prince Caramanico, the Neopolitan ambassador. Lunardi had arranged to take an Englishman with him, but as there was insufficient hydrogen to sustain the extra weight, he was compolled to go alone. The balloon was provided with oars intended to raise or lower it at will, but one oar broke and fell to the ground. After $1 \frac{1}{\mathrm{~h}} \mathrm{hr}$. Lunardi descended at South Mimms in Hertfordshire to land the cat, which had suffered from the cold-the pigeon had already escaped-and made a second descent threequarters of an hour later near Ware, having drifted twenty-four miles. This exploit excited enormous enthusiasm, and the balloon was exhibited for profit at the Lyceum in the Strand. In the following year Lunardi made several successful ascents from Kelso, Edinburgh and Glasgow. His letters to his guardian, Chevalier Compagni, which were published, contain a vivid account of his pioneer ventures. A strikingly handsome man, Lunardi died on July 31,1806 , at the age of forty-seven.

\section{Building Research}

ThE Lord President of the Council and the Minister of Works have decided that the Department of Scientific and Industrial Research should in future be the only Government department with responsibility for building research. Hitherto, the Ministry of Works has shared this responsibility through the Advisory Council on Building Research and Development. This Council, which was set up in 1947, and has made a most valuable contribution to the whole field of building research, will therefore not be continued after its present two-year period expires in March. To ensure continuity of the work previously undertaken by the Advisory Council, the Department of Scientific and Industrial Research will invite the various sections of the building industry to nominate representatives to a Standing Conference on Building Research and Development. The Ministry of Works will continue to provide the present service of advisory leaflets, lectures and the technical information service.

\section{United States Atomic Energy Commission Charges for Uranium-233 and Plutonium}

The United States Atomic Energy Commission has established the charges at which uranium-233 and plutonium will be made available for use in research and development to private individuals and companies in the United States and to foreign governments under agreements for co-operation, at 